\title{
Extreme politieke oriëntaties in Europa Verklaringen op micro- en macroniveau
}

\author{
Mark Visser, Eva Jaspers \& Gerbert Kraaykamp ${ }^{1}$
}

\section{Summary}

Extreme political ideologies in European countries. Explanations at the individual and country-level

In this study, we set out to explain extreme left-wing and extreme right-wing ideologies within and between 30 European countries in a multi-level framework. To test our hypotheses, we use data from the European Social Surveys of 2002, 2004, 2006, 2008 and $2010(N=176.803)$, enriched with country characteristics. Our results show that lower educated people and manual workers are more likely to support left-wing extremism, because they are of the opinion that the government should take measures to reduce differences in income levels. Interestingly, the lower educated and manual workers are also more likely to have an extreme right-wing ideology. This effect, however, is explained by a higher level of perceived ethnic threat. At the country-level, our analyses indicate that a heritage of a totalitarian regime increases the likelihood for an individual to hold an extreme left-wing and extreme right-wing ideology. Moreover, we found a positive effect of the percentage of unemployed people in a country on the probability to support left-wing extremism.

\section{Achtergrond en probleemstelling}

Binnen Europa is al enige tijd een trend richting politieke polarisatie waarneembaar (Pugh, 2009; Thomassen, 2005): zowel politieke partijen als hun electoraat bewegen qua ideologie weg van het midden (Mair, Müller \& Plasser, 2004). In deze bijdrage onderzoeken we wie in Europa extreme posities op het bekende politieke links-rechts continuüm inneemt. Op dit continuüm wordt iemand die streeft naar inkomensni- 
vellering vaak als links beschouwd en gaan rechtse personen meer uit van het vrijemarktprincipe. Hoewel wetenschappers verschillende nieuwe dimensies hebben geïntroduceerd die het politieke speelveld completer beschrijven, zoals de autoritair-libertaire dimensie (zie Middendorp, 1991), begrijpen kiezers de links-rechts schaal vaak als breder dan alleen economisch. Zorg voor het milieu en integratiebeleid zijn voorbeelden van issues die kiezers kunnen relateren aan links of rechts (Abramowitz \& Saunders 2008; Jost, Federico \& Napier, 2009). Kiezers zien de linksrechts schaal derhalve als een samenvatting van verschillende politieke kwesties. In deze studie richten we ons op verklaringen voor de mate van politiek extremisme (in zelfplaatsing) van individuen in dertig landen binnen Europa.

In diverse internationale publicaties worden de termen extreem, populistisch, radicaal en ver rechts aangehaald en los gehanteerd om het uiteinde aan de rechterkant van de schaal te beschrijven (Mudde, 1996). We kiezen binnen deze studie voor de formulering extreem rechts. ${ }^{2}$ Extreem rechts is daarbij niet identiek aan het aanhangen van fascistische of nazistische denkbeelden (Kitschelt, 2007). Wel zijn personen met een extreem rechtse oriëntatie vrijwel altijd etnocentrisch (Coenders, 2001; Scheepers, 1996). Verder beargumenteert Mudde (2007) dat deze personen gekenmerkt worden door een autoritaire en nationalistische houding. Autoritair betekent daarbij sterk normatief richtinggevend op het terrein van levenskeuzen, zoals abortus en euthanasie.

Op het andere uiteinde van het politieke toneel zijn de personen met een extreem linkse oriëntatie gepositioneerd. Zij kenmerken zich door een eigen leefstijl en visie op het functioneren van de maatschappij. Men streeft vooral naar gelijkheid en verwerpt het kapitalisme (Ooijevaar \& Kraaykamp, 2005). De consumptiemaatschappij wordt gehekeld en soms is men zelfs geheel tegen privébezit. Nieuwe sociale bewegingen aan de linkerzijde van het politieke spectrum vertegenwoordigen het milieu of stromingen zoals het antifascisme, antiglobalisme en dierenactivisme (Giddens, 1994). Naast politieke demonstraties en protestmarsen gebruiken aanhangers van deze stromingen soms geweld om hun doeleinden na te streven. Dit geldt overigens ook voor aanhangers van het rechts extremisme. March en Mudde (2005) beschrijven dat extreem links in Europa aan populariteit inboette na de val van het communisme, maar ook dat er tegenwoordig kansen liggen voor sociaal-populistische partijen alsmede de antiglobalisme beweging.

Studies naar de sociale achtergronden van personen met een extreem linkse oriëntatie zijn zeer schaars. Verklaringen voor extreem rechtse orientaties zijn daarentegen al wel vaker getoetst. In het huidige onderzoek trachten we met verschillende theoretische mechanismen te verklaren waarom bepaalde sociale groepen zowel vaker extreem links als extreem 
rechts zijn. Daartoe formuleren we intermediërende hypothesen. Een additionele kwestie is of de verklaringsmechanismen voor extreem linkse en extreem rechtse identificatie op elkaar lijken, zoals soms wordt gesuggereerd (Faye, 2004), of dat beide extremen op elkaar reageren en vervolgens polarisatie in de hand werken (Oosterwaal, 2009). Tevens varieert de populariteit van extremistische bewegingen en partijen van land tot land. Om verschillen tussen landen en ook individuen te verklaren, hanteren we in deze studie een geïntegreerde benadering waarin invloeden op micro- en macroniveau tegelijkertijd voor zowel extreem links als extreem rechts worden getoetst. Daarbij leiden we hypothesen af over landkenmerken (te weten: totalitaire regimes en secularisatie) die tot op heden niet zijn verdisconteerd in studies naar extreem rechts. Bovendien is naar ons weten nooit onderzoek verricht naar landkenmerken die van invloed zijn op links extremisme. Deze bijdrage geeft aldus antwoord op de volgende probleemstelling: In hoeverre verklaren individuele kenmerken en landkenmerken extreem linkse en extreem rechtse politieke oriëntaties van individuen in Europa?

\section{Theorieën en hypothesen}

Er bestaat een rijke onderzoekstraditie naar politieke overtuigingen en stemgedrag. Een van de benaderingen onderzoekt extremisme in zijn algemeen, waarbij de inhoud van het extreme standpunt als minder relevant wordt beschouwd. We bespreken in paragraaf 2.1 daarom eerst deze theorieën. Daarnaast zijn er verschillende theorieën die zich richten op verklaringen voor specifiek links dan wel rechts extremisme. In paragraaf 2.2 bespreken we de belangrijkste stromingen binnen deze benadering.

\section{I Algemene verklaringen voor extremisme}

Twee theorieën zijn historisch van belang geweest in het onderzoek naar extremisme: de gezaghebbende extremismetheorie en de contexttheorie. Beide veronderstellen een invloed van kennis en interesse op de mate van extremisme van een persoon, zij het tegengesteld. De extremismetheorie stelt dat sommige personen extremer zijn, omdat ze de complexe sociale werkelijkheid niet begrijpen. Daardoor zouden ze versimplificeren en de wereld in zwart-wit zien. Extremisten zouden zich daarom voornamelijk bevinden onder lager opgeleiden of personen met weinig politieke kennis (Rokeach, 1967). Het is niet altijd even gemakkelijk om bepaalde beleidsmaatregelen of politieke processen te begrijpen, hetgeen kan leiden tot onzekerheid. Extremisten zouden deze politieke onzekerheid maskeren door het innemen van stellige posities. De con- 
texttheorie stelt daarentegen dat personen die zich onzeker voelen over hun eigen mening geneigd zijn om het veilige midden van de schaal op te zoeken (Sidanius, 1985). Ze zijn bijvoorbeeld angstig om hun mening te verkondigen, omdat anderen deze mening kunnen tegenspreken of omdat ze bang zijn voor sociale uitsluiting. Volgens deze benadering zijn het juist de hoger opgeleiden of politiek geletterden die zich zeker genoeg voelen over hun standpunten om extreme meningen op te zoeken. In de psychologische literatuur is de extremismetheorie opgevolgd door de sociale dominantietheorie, terwijl de contexttheorie grotendeels is verdwenen uit het hedendaagse onderzoek. De sociale dominantietheorie veronderstelt dat personen die worden geconfronteerd met onzekerheid of een gebrek aan invloed ervaren, geneigd zijn rigide te reageren, onder andere door weinig genuanceerde - en dus extreme - standpunten in te nemen (Greenberg \& Jonas, 2003; Sidanius, 1993; Sidanius \& Pratto, 1999). Deze onzekerheid kan onder meer betrekking hebben op het levensonderhoud van mensen. Zo kunnen personen die moeilijk kunnen rondkomen tevens het gevoel hebben dat ze niets aan deze situatie kunnen veranderen. Volgens Nozick (1997) zijn zij op zoek naar extremistische ideeën, omdat zij geen vertrouwen hebben in de heersende politiek. Sterker nog, zij geloven in ideologieën en maatregelen die een hiërarchische samenleving verkondigen waarin sommige groepen inferieur zijn aan andere (Pratto, Sidanius, Stallworth \& Malle, 1994).

\subsection{Specifieke verklaringen voor links en rechts extremisme}

Naast algemene ideeën over extremisme, bestaan er ook theorieën die zich specifiek richten op links en rechts extremisme. De traditionele verklaringen voor politieke oriëntaties komen voort uit drie scholen: de economische, (sociaal-)psychologische en sociologische benadering.

De economische benadering, benadrukt door Schumpeter (1943), stelt dat individuen rationeel handelen. Zij evalueren aan de hand van informatie over de beleidsvoorstellen van partijen, welke partij het meest in hun (economisch) belang handelt. Die partij krijgt dan vervolgens hun stem. De econoom Downs (1957) ging daarbij voornamelijk uit van het feit dat men retrospectief stemt. Personen gebruiken informatie uit het verleden om te evalueren welke partij het meest in hun economische belang heeft gehandeld. Regeringspartijen zouden zodoende afgestraft of beloond worden voor prestaties in de afgelopen regeringsperiode. Beleid dat als minder voordelig wordt gepercipieerd, kan daarbij politieke polarisatie in de hand werken.

Ten tweede is er de (sociaal-)psychologische benadering. Deze benadering richt zich op het belang van attitudes en percepties. Een voorbeeld 
binnen deze theoretische stroming is dat van de autoritaire persoonlijkheid (Adorno, Frenkel-Brunswik, Levinson \& Nevitt Sanford, 1950), die gezag, orde en een sterke leider wenst (Stenner, 2005). Daarnaast speelt het contrast tussen materialistische en postmaterialistische waarden en normen een rol. Iemand die materialistische doelen nastreeft, zal economische groei en veiligheid prioriteit geven. Een postmaterialist zal een schoner milieu en tolerantie ten opzichte van etnische minderheden belangrijk vinden (Inglehart, 1997).

Ten derde stelt de sociologische benadering dat groepslidmaatschap van invloed is op politieke oriëntaties. Naarmate men hechter is geïntegreerd in een groep, zal men meer groepsconform politiek georienteerd zijn om loyaliteit ten opzichte van deze groep uit te drukken (Lazarsfeld, Berelson \& Gaudet, 1944). Sociaal-demografische kenmerken zijn de voornaamste verklarende factoren binnen deze school. Zo liet Need (1997) zien dat zowel sociale klasse van de ouders als kerkelijkheid van de ouders bij stemgedrag relevant is. Eerder onderzoek naar politiek extremisme binnen de sociologische benadering maakt veelal gebruik van de etnische competitietheorie en de theorie van symbolische belangen. Deze theorieën zullen we bij het afleiden van onze hypothesen nader uiteenzetten.

Lipset en Rokkan (1967) vermelden binnen de sociologische benadering dat politieke tegenstellingen de bestaande sociale structuren in de maatschappij weerspiegelen. In alle westerse industrielanden blijkt sociale klasse een zeer belangrijke determinant van politieke oriëntaties te zijn. Nieuwbeerta (1995) spreekt in dit licht van een democratische klassenstrijd, waarin handarbeiders een grotere kans bezitten om links te zijn in vergelijking tot personen afkomstig uit hogere klassen. Personen met een linkse oriëntatie zijn namelijk veelal, in tegenstelling tot personen met een rechtse oriëntatie, voor grotere gelijkheid in een samenleving. De sterkte van de relatie tussen sociale klasse en politieke oriëntatie is in de meeste westerse democratieën afgenomen in de periode na de Tweede Wereldoorlog (Clark, Lipset \& Rempel, 1993; Nieuwbeerta, 1995).

De uiteengezette theoretische benaderingen van politieke oriëntaties zijn voornamelijk van toepassing op individuen, maar hebben tevens consequenties voor verschillen tussen samenlevingen qua extreem linkse en extreem rechtse oriëntaties. Op deze wijze kunnen we nationale processen blootleggen die polarisatie versterken. Onze focus ligt op het verklaren van zowel links als rechts extremisme. Derhalve specificeren we onze hypothesen waar mogelijk naar extreem links en extreem rechts. 


\subsection{Verklaringen op het microniveau}

Allereerst leiden we een intermediërende hypothese af vanuit de etnische competitietheorie binnen de sociaal-psychologische en sociologische benadering. Deze theorie stelt dat binnen elke samenleving bronnen bestaan voor realistische conflicten tussen groepen over schaarse goederen (zoals macht en status) alsook over conflicterende waarden. Deze intergroep competitie kan leiden tot sterkere solidariteit met de eigen groep en tot vijandigheid jegens andere groepen (Blalock, 1967; Coser, 1956). Hoe sterker de competitie tussen etnische groepen, hoe sterker de etnocentrische reactie, onder de voorwaarde dat competitie ook wordt waargenomen (LeVine \& Campbell, 1972). Personen uit lagere sociale klassen komen meer in aanraking met etnische minderheden dan personen uit hogere klassen, omdat zij bijvoorbeeld vaker concurreren op de arbeidsmarkt en in dezelfde wijken wonen. Dit betekent dat personen met een lagere beroepspositie meer etnische dreiging ervaren, bijvoorbeeld in de concurrentie om banen, scholing en woningen. Ervaren etnische dreiging zou vervolgens leiden tot een grotere kans op een extreem rechtse oriëntatie, omdat extreem rechtse bewegingen claimen de belangen van autochtonen te behartigen (Lubbers, Gijsberts \& Scheepers, 2002; Rydgren, 2007). Personen uit de lagere sociale klassen zijn dus vaker extreem rechts, juist omdat zij meer etnische dreiging ervaren. Uit een studie van Norris (2005) blijkt dat weerstand tegen etnische minderheden de belangrijkste verklaring biedt voor steun aan extreem rechts in West-Europa. De eerste hypothese op microniveau is als volgt geformuleerd: (H1a) Lager opgeleiden, (H1b) handarbeiders en (H1c) werklozen hebben een grotere kans op een extreem rechtse oriëntatie dan hoger opgeleiden, hoofdarbeiders en werkenden, (H1d) omdat zij meer etnische dreiging ervaren.

Voor extreem links kan ook voor lager opgeleiden, handarbeiders en werklozen een intermediërende hypothese worden afgeleid. Het is met name interessant om voor dezelfde sociale achtergrondkenmerken verschillende verklaringen te opperen waarom zij extreem links of extreem rechts zijn, aangezien deze mechanismen kunnen verschillen en derhalve differentiële sociale processen kunnen blootleggen. Hier kijken we daarom naar de gewenste mate van inkomensnivellering in plaats van etnische dreiging. Vanuit traditioneel oogpunt stemmen lager opgeleiden en personen uit de handarbeidersklasse links (Nieuwbeerta, 1995). Zij streven naar inkomensgelijkheid in de samenleving en een betere situatie voor henzelf. Voor extreem links betekent dit soms ook een verwerping van de gehele kapitalistische ideologie. Daarnaast spannen personen met een extreem linkse oriëntatie zich bovengemiddeld in voor anti-kapitalistische bewegingen. Werklozen zouden vooral participeren in dergelijke bewegingen, omdat zij gezien hun situatie de samenleving willen veranderen. Baanverlies kan namelijk ontevredenheid over het 
systeem oproepen. Een van de weinige verklarende studies naar extreem links is die van Ooijevaar en Kraaykamp (2005) voor Nederland. Zij lieten zien dat personen met een extreem linkse oriëntatie weinig economische hulpbronnen hebben en vaker werkloos zijn. Daarnaast kunnen we vanuit de sociale dominantietheorie stellen dat zij meer onzekerheid ervaren over hun bestaan. Personen uit de lagere sociale klassen vinden derhalve dat inkomensongelijkheid gereduceerd dient te worden. Aangezien het bestrijden van inkomensongelijkheid een speerpunt van extreem links is, verklaart dit waarom lager opgeleiden, handarbeiders en werklozen vaker het links extremisme aanhangen. Zij zijn namelijk relatief slechter af. De verwachting luidt: (H2a) Lager opgeleiden, (H2b) handarbeiders en $(\mathrm{H} 2 \mathrm{c})$ werklozen hebben een grotere kans op een extreem linkse oriëntatie dan hoger opgeleiden, hoofdarbeiders en werkenden, (H2d) omdat zij vinden dat inkomensongelijkheid gereduceerd dient te worden.

Hoewel de trend richting secularisatie in veel Europese landen optreedt, is religie nog altijd een belangrijke verklarende factor in sociaal-wetenschappelijk onderzoek naar politieke oriëntaties. De theorie van symbolische belangen beredeneert dat personen die minder hecht zijn geïntegreerd in de intermediaire groeperingen binnen de samenleving, op zoek kunnen gaan naar alternatieven voor integratie (Arendt, 1951; Kornhauser, 1960). Daarmee leunt deze theorie sterk op de eerder uiteengezette sociologische benadering. Extreem linkse en extreem rechtse groeperingen/partijen kunnen via hun denkbeelden een alternatief voor integratie bieden. Niet-religieuze personen vormen een groep minder verbonden individuen die wellicht streven naar sociale identificatie met een groter geheel (Scheepers, Billiet \& De Witte, 1995). Uit eerder onderzoek blijkt dat zij een grotere kans hebben om extreem links (Ooijevaar \& Kraaykamp, 2005) en extreem rechts (Van der Brug, 2003) te zijn. Daarbij komt dat religieuze personen in de politiek vaak vertegenwoordigd worden door een partij met een religieuze grondslag. Deze partijen bevinden zich vaak in het politieke centrum. Als een gevolg zouden niet-religieuze personen kunnen wegtrekken van dit centrum. Onze volgende hypothese luidt: Niet-religieuze personen hebben een grotere kans op een (H3a) extreem linkse en (H3b) extreem rechtse oriëntatie dan religieuze personen.

\subsection{Verklaringen op het macroniveau}

De historie van Europese landen loopt zeer uiteen waar het hun regeringsvorm betreft. Na de Tweede Wereldoorlog kenden bijvoorbeeld Griekenland, Italië, Portugal, Spanje en veel Oost-Europese landen een totalitair regime. Dictaturen trachten via propaganda en populisme brede steun onder de bevolking te winnen. Een dictoriaal verleden kan 
daarbij een voedingsbodem voor extreem linkse dan wel extreem rechtse bewegingen bieden. Zo beredeneert Husbands (1998) dat steun voor extreem rechts in deze landen een gevolg is van de verscheidene en nog altijd bestaande organisaties daterend uit het fascistische tijdperk. Dit sluit deels aan bij de sociologische benadering, aangezien aanhangers of leden van deze organisaties stemmen volgens de groepsnorm. Daarnaast is er in een land dat een totalitair regime heeft gekend vanuit het verleden meer scepsis over het functioneren van de regering. De sociale dominantietheorie stelt dat deze onzekerheid over de politiek als gevolg heeft dat personen wegtrekken uit het centrum en extremere standpunten innemen. Zo hebben personen die wonen in landen met een dictatoriaal verleden (nog) niet in dezelfde mate kunnen profiteren van meer democratische beleidsmaatregelen met betrekking tot gezondheidszorg en sociale zekerheid. Vanuit de sociale dominantietheorie redenerend, zou de afwezigheid van dergelijke regelingen tot meer onzekerheid bij personen kunnen leiden. Betz (1994) stelt bovendien dat steun aan extreme groeperingen of partijen voortkomt vanuit een diepgewortelde verwerping van democratie. In deze studie gaan we uit van de situatie na de Tweede Wereldoorlog. Immers onze respondenten zijn in deze periode opgegroeid. Onze eerste macrohypothese luidt: In een land dat een totalitair regime heeft gekend na 1945 is de kans voor een individu op een (H4a) extreem linkse en (H4b) extreem rechtse oriëntatie groter dan in een land dat geen totalitair regime heeft gekend na 1945.

Voorts vermoeden we dat immigratie een belangrijke determinant voor een extreem rechtse politieke oriëntatie is. De eerder uiteengezette etnische competitietheorie stelt dat etnische groepen belang hebben bij de verwerving van schaarse goederen. De ervaren concurrentie tussen deze etnische groepen leidt vervolgens tot etnocentrisme (Gijsberts, Hagendoorn \& Scheepers, 2004) en tot een grotere kans op het stemmen op een extreem rechtse partij (Lubbers e.a., 2002). Quillian (2006) meent dat niet de bedreiging van persoonlijke belangen, maar ook bedreigingen van groepsbelangen etnocentrische reacties doet versterken. Belangrijk is hierbij dat een toename in de mate van etnische competitie veroorzaakt kan worden door de immigratie van etnische minderheden (Olzak, 1992). Zo kwamen Carter (2005) en Van der Brug, Fennema en Tillie (2005) in meerdere landen tot de conclusie dat immigratie de populariteit van extreem rechtse opvattingen verklaart. Immigranten kunnen tevens als een bedreiging gezien worden voor de cultuur van een land. Op deze wijze kan een conflict ontstaan met de waarden en normen uit de rechts extreme ideologie. Er is ons geen literatuur bekend over het verband tussen immigratie en extreem linkse oriëntaties. We formuleren daarom geen hypothese over deze relatie. Wat betreft extreem rechts spreken we de volgende verwachting uit: (H5) Hoe hoger het percentage 
immigranten in een land, des te groter de kans voor een individu op een extreem rechtse oriëntatie.

De economische situatie in een land kan ook van invloed zijn op de politieke oriëntaties van haar inwoners. Wanneer het economisch slecht gaat en het percentage werklozen in een land hoger ligt, zullen individuen dit volgens de gedachtegang van de conflicttheorie projecteren op andere groepen (Blalock, 1967; Coser, 1956). Onafhankelijk van het percentage immigranten, versterkt een slechtere economische situatie de competitie in een land. Dit zou betekenen dat personen uit een land met een hoger werkloosheidspercentage meer dreiging ervaren in de concurrentie om banen en derhalve een grotere kans hebben om extreem rechts te zijn. Eerder landenvergelijkend onderzoek naar extreem rechts vond echter geen eenduidig effect van het werkloosheidspercentage (Arzheim \& Carter, 2006; Lubbers e.a., 2002). Ook de kans op een extreem linkse oriëntatie kan beïnvloed worden door een hoger werkloosheidspercentage. In economisch slechtere tijden zal de bevolking hiervan hinder ondervinden. Men streeft dan wellicht sterker naar gelijkheid en verwerpt eventueel zelfs het gehele kapitalistische systeem, kenmerkend voor een extreem linkse gedachtegang. Bovendien kunnen we uit de sociale dominantietheorie afleiden dat in tijden van economische onzekerheid, individuen eerder geneigd zijn extreme posities in te nemen. Onze derde hypothese luidt: Hoe hoger het werkloosheidspercentage in een land, des te groter de kans voor een individu op een (H6a) extreem linkse en (H6b) extreem rechtse oriëntatie.

De kerk is een van de belangrijkste intermediaire groeperingen in de maatschappij. Echter, de invloed van de kerk neemt af en steeds minder personen hangen een geloof aan. Naarmate een land sterker is geseculariseerd, des te minder zullen de kerkelijke waarden en normen prevaleren onder de gehele bevolking. In een dergelijk klimaat kunnen mensen meer interesse gaan tonen in bewegingen die opkomen voor dierenwelzijn, het antiglobalisme en het anti-kapitalisme. De waarden en normen die de kerk propageert, zijn moeilijk verenigbaar met extreem rechts. Personen die zichzelf als lid beschouwen van een geloofsgemeenschap zijn gesocialiseerd met een veelomvattend wereldbeeld waarin naastenliefde belangrijk wordt geacht en dat komt niet overeen met extreem rechtse denkbeelden. Dit veelomvattende wereldbeeld zal minder sterk prevaleren in landen waarin secularisatie verder is voortgeschreden. Bovendien kan de kerk in deze landen minder tegenwicht bieden aan extreme groeperingen. Dit leidt tot de volgende verwachting: Hoe hoger het percentage niet-religieuze personen in een land, des te groter de kans voor een individu op een (H7a) extreem linkse en (H7b) extreem rechtse oriëntatie. 


\subsection{Cross-level interacties}

Tot nu toe lag de aandacht bij het verklaren van individuele en contextuele verschillen in de mate van politiek extremisme. Er kunnen echter verschillen tussen landen bestaan in de sterkte van de effecten van individuele factoren. In lijn met de etnische competitietheorie verwachten we dat lager opgeleiden, handarbeiders en werklozen relatief vaker extreem rechts zijn. Onze verwachting is daarenboven dat de personen uit de lagere sociale lagen gevoelig zijn voor contextuele omstandigheden - zoals een hoger percentage immigranten - die de interetnische concurrentie versterken. Juist zij ervaren in tegenstelling tot personen uit hogere sociale klassen namelijk vaker concurrentie van etnische minderheden, bijvoorbeeld op de arbeidsmarkt, waardoor baanzekerheid kan afnemen. Hierdoor stijgt de kans op een extreem rechtse oriëntatie (Lubbers e.a., 2002). Hoger opgeleiden zullen bijvoorbeeld minder gevoelig zijn voor immigratie, omdat zij niet zo vaak hoeven te concurreren met immigranten. We leiden de volgende verwachting af: (H8a) Lager opgeleiden, (H8b) handarbeiders en $(\mathrm{H} 8 \mathrm{c})$ werklozen hebben een grotere kans op een extreem rechtse oriëntatie, naarmate het percentage immigranten in een land toeneemt.

Eenzelfde mechanisme kan worden toegepast als het gaat om de economische situatie in een land. Het idee is dat een slechtere economische situatie zoals een hoger werkloosheidspercentage de competitie in een land versterkt. Immers, de concurrentie om schaarse goederen, mede door krapte op de arbeidsmarkt of minder sociale zekerheid, zal in economisch slechtere tijden toenemen. De aantrekkingskracht van extreem rechts neemt als gevolg toe voor personen uit de lagere sociale strata. Ook het effect van sociale klasse op de kans op een extreem linkse politieke oriëntatie kan variëren tussen landen. Lager opgeleiden, handarbeiders en werklozen zijn volgens onze verwachting relatief vaker extreem links. Juist zij worden door een slechte economische situatie en een hoog percentage werklozen getroffen, waardoor zij wellicht nog sterker zullen streven naar gelijkheid. Tevens kan een slechte economische periode in een land volgens de sociale dominantietheorie onzekerheid oproepen onder haar inwoners. Het proces van polarisatie wordt voor hen versterkt in de richting van extreem links. Dit resulteert in de hypothese: (H9a) Lager opgeleiden, (H9b) handarbeiders en (H9c) werklozen hebben een grotere kans op een extreem linkse en extreem rechtse oriëntatie, naarmate het werkloosheidspercentage in een land toeneemt.

Tot slot kan de mate van secularisatie in een land van invloed zijn op het individuele effect van religie. Vanuit de theorie van symbolische belangen is afgeleid dat niet-religieuze personen zich vaker op de uiteinden van het links-rechts continuüm bevinden dan religieuze personen, omdat zij mogelijk op zoek zijn naar een substituut voor integratie. In 
een samenleving waarin de kerk steeds minder belangrijk wordt, neemt het aantal niet-religieuze personen toe. Het geloof boet aan waarde in. Religieuze personen zouden zich in dergelijk geseculariseerde samenlevingen sterker kunnen gaan houden aan hun waarden en normen, terwijl niet-religieuze personen in een dergelijk klimaat zich nog sterker afzetten tegen de kerk en op zoek gaan naar alternatieve symbolische integratie. Zowel links als rechts extremisme kan dan uitkomst bieden. Onze laatste hypothese luidt derhalve: Niet-religieuze personen hebben een grotere kans op een (H10a) extreem linkse en (H10b) extreem rechtse oriëntatie, naarmate het aantal niet-religieuze personen in een land toeneemt.

\subsection{Extreem links versus extreem rechts}

Tot slot is het contrast tussen extreem links en extreem rechts interessant. We willen namelijk nagaan of personen met een extreem linkse dan wel extreem rechtse oriëntatie op elkaar lijken of wezenlijk van elkaar verschillen. Het politieke links-rechts continuüm kan enerzijds worden voorgesteld als een rechte lijn waarop extreem links en extreem rechts op beide uiteinden van deze lijn liggen. Bij een dergelijke zienswijze is de verwachting dat extreem links en extreem rechts weinig met elkaar gemeen hebben en zich tegen elkaar afzetten (Oosterwaal, 2009). Anderzijds wordt de hoefijzervorm geopperd, waarbij de beide uiteinden van het politieke spectrum bepaalde aspecten met elkaar gemeen hebben (Faye, 2004). Zo zouden beide extremen geweld legitimeren om maatschappelijke verandering teweeg te brengen. Een sterke overeenkomst tussen personen met een extreem linkse en extreem rechtse orientatie kan er bovendien op duiden dat de sociale dominantietheorie opgang vindt. De vergelijking tussen de beide extreme oriëntaties heeft in onze analyses een exploratief karakter.

\section{Data en meetinstrumenten}

\section{I Data}

Om onze hypothesen te toetsen, maken we gebruik van vijf ronden (2002, 2004, 2006, 2008 en 2010) van het European Social Survey (ESS). De dataset bevat informatie over 213.880 individuen in dertig landen. ${ }^{3}$ De ESS dataverzameling vindt tweejaarlijks plaats onder inwoners van Europa van 15 jaar en ouder via face-to-face interviews. Meer informatie over de ESS is beschikbaar via www.europeansocialsurvey.org.

Aangezien de minimumleeftijd voor stemrecht in de meeste Europese landen 18 jaar is, zijn alleen individuen van 18 jaar en ouder geselecteerd voor onze analyses. Na deze selectie blijven er 205.934 respon- 
denten over. Vervolgens zijn 29.131 respondenten $(14,2 \%)$ uit de dataset verwijderd, omdat zij missende informatie hadden op onze afhankelijke variabele. Verder zijn alle missende waarden op onze onafhankelijke variabelen ingevuld door middel van multipele imputatie. De uiteindelijke gestapelde dataset bevat gegevens over 176.803 respondenten.

\subsection{Operationaliseringen}

Onze afhankelijke variabele politieke oriëntatie is gemeten op een schaal van 0 (uiterst links) tot en met 10 (uiterst rechts), waarop respondenten konden aangeven hoe zij hun politieke oriëntatie beoordelen. Het voordeel van links-rechts zelfplaatsing boven stemgedrag is dat zo voor onderzoekers een duidelijke indicator voor het behoren tot extreem links en extreem rechts voorhanden is. Er hoeft namelijk geen discussie gevoerd te worden over welke politieke partijen al dan niet extreem zijn. Vooral wat betreft extreem links is dit een lastige horde. Daarnaast is het aantal missende waarden op links-rechts zelfplaatsing zeer klein in vergelijking met stemgedrag. Met name het behouden van de niet-stemmers is zeer relevant: zij hebben namelijk naar verwachting een extreme oriëntatie. De categorieën 0 en 1 zijn samengevoegd tot 'extreem links'. De categorieën 9 en 10 tot 'extreem rechts'. Categorieën 4 tot en met 6 vormen het politieke centrum. In Europa is 5,5\% van de respondenten extreem links tegenover 6,0\% extreem rechts. Als we alleen 0 als extreem links en alleen 10 als extreem rechts beschouwen is slechts een gering aantal personen als extreem te kenschetsen. Het gemiddelde percentage personen met een extreem linkse en extreem rechtse oriëntatie in een land komt dan in beide gevallen net boven de 3\% uit en in diverse landen zelfs onder de $2 \%$, hetgeen onwenselijk is bij een logistische multiniveau-analyse. Een sensitiviteitsanalyse wees desondanks uit dat bij een dergelijke operationalisatie de relevante effecten niet tot nauwelijks afwijken van de in deze studie gepresenteerde resultaten.

Met betrekking tot opleidingsniveau is gevraagd naar de hoogst voltooide opleiding van de respondent. We onderscheiden de categorieën 'primair', 'secundair' en 'tertiair'. Het beroep van de respondent hebben we volgens het EGP klassenschema ingedeeld naar 'hoofdarbeid' en 'handarbeid'. Deze variabele is aangevuld met 'werkloos' en 'overige' (onder andere huisvrouwen en studenten). Deze indeling beperkt het aantal 'random' effecten en cross-level interacties in onze modellen. Een uitgebreidere indeling leverde schattingsproblemen op. Daarnaast zijn we voornamelijk geïnteresseerd in de verschillen in de mate van links en rechts extremisme tussen enerzijds hoofdarbeiders en anderzijds handarbeiders en werklozen. Het al dan niet aanhangen van een religie is gemeten met de vraag of de respondent zichzelf beschouwt als lid 
van een kerk of geloofsgemeenschap ( $0=$ 'wel', $1=$ 'niet'). De intermedierende factor ervaren etnische dreiging is gemeten door drie items die cross-nationaal vergelijkbaar zijn (Coenders, Lubbers \& Scheepers, 2004), te weten: 'Is het volgens $u$ over het algemeen slecht of goed voor de economie dat mensen uit andere landen hier komen wonen?' $(0=$ 'goed voor de economie', 10 = 'slecht voor de economie'), 'Vindt $u$ dat het culturele leven over het algemeen ondermijnd of verrijkt is door mensen uit andere landen die hier zijn komen wonen?' ( 0 = 'culturele leven is verrijkt', 10 = 'culturele leven is ondermijnd') en 'Is dit land, door mensen uit andere landen die hier zijn komen wonen, een slechtere of betere plek geworden om te wonen?' (0 = 'betere plek om te wonen', 10 = 'slechtere plek om te wonen'). De scores op de items zijn bij elkaar opgeteld (Cronbachs $\alpha=0,87$ ). Om de intermediërende variabele attitude ten aanzien van inkomensverschillen te meten, is gevraagd in hoeverre men het eens is met de stelling: 'De overheid zou maatregelen moeten nemen om inkomensverschillen te verminderen'. Respondenten konden antwoorden op een schaal lopend van 'helemaal oneens' (1) tot 'helemaal eens' (5).

Als controlevariabelen worden etniciteit ( 0 = 'autochtoon', 1 = 'allochtoon'), ouderlijk opleidingsniveau, leeftijd (in jaren) en burgerlijke staat ('gehuwd', 'gescheiden', 'weduwnaar/weduwe' en 'ongehuwd') meegenomen. We beschouwen iemand als allochtoon wanneer één van beide (of beide) ouders in het buitenland is (zijn) geboren. We nemen zodoende zowel eerste als tweede generatie allochtonen mee in onze analyses. Zowel de hoogst voltooide opleiding van de vader als dat van de moeder is ingedeeld in de categorieën 'primair', 'secundair' en 'tertiair'. Daarbij hebben we de keuze gemaakt om het hoogst behaalde opleidingsniveau van een van beide ouders als indicatie voor het opleidingsniveau van de ouders te nemen. Eerder onderzoek heeft aangetoond dat mannen een grotere kans hebben op een extreem rechtse oriëntatie dan vrouwen (Givens, 2004). Daarom wordt gecontroleerd voor geslacht (0 = 'vrouw', $1=$ 'man'). Verder verwachten we dat men gematigder wordt, naarmate men (meer) kinderen heeft. Het aantal kinderen is daarom opgenomen in onze analyses. Tevens wordt rekening gehouden met de ronde van het survey.

Op het landniveau nemen we een dichotome variabele op die aangeeft of een land al dan niet een totalitair regime heeft gekend na 1945 $(0=$ geen totalitair regime, $1=$ wel totalitair regime). Verder nemen we het percentage immigranten in een land in 2005 op, verkregen uit de rapportage World Population Policies 2005 (VN, 2006). ${ }^{4}$ De maat voor secularisatie is het percentage niet-religieuze personen in een land per ESSronde. De percentages zijn per land en ESS-ronde geaggregeerd vanuit de individuele variabele religie. Tot slot is het werkloosheidspercentage per land en jaar meegenomen. De cijfers zijn afkomstig van de datasec- 
tie van de website van de 'International Labour Organization' (ILO). De correlaties tussen deze landkenmerken zijn zwak tot matig en geven geen aanleiding tot ongerustheid met betrekking tot multicollineariteit. Een robuustheidtest is uitgevoerd door alle landkenmerken separaat te schatten in een model met alle predictoren op het individuele niveau. Dit had geen significante gevolgen voor de resultaten. Beschrijvende statistieken staan weergegeven in tabel 1 .

\subsection{Analyse}

Om rekening te houden met de genestheid van individuen in een land maken we gebruik van multiniveau-analyse, waarmee regressiecoëfficiënten en de bijbehorende standaardfouten zuiverder worden geschat (Snijders \& Bosker, 1999). Er zijn drie logistische multiniveau-analyses uitgevoerd in MLwiN: extreem rechts versus rechts en centrum (tabel 2), extreem links versus links en centrum (tabel 3) en extreem links versus extreem rechts (tabel 4). Het gebruik van multinomiale modellen was niet mogelijk, aangezien deze niet convergeerden wegens een te groot aantal respondenten in combinatie met random effecten en cross-level interacties.

De landvariantie is in alle nulmodellen significant. Voor extreem rechts en extreem links wordt respectievelijk $11,4 \%$ en $7,4 \%$ van de totale variantie veroorzaakt door verschillen tussen landen. In model 1 worden alle individuele en contextuele kenmerken toegevoegd. Vervolgens nemen we in model 2 van tabel 2 ervaren etnische dreiging en in model 2 van tabel 3 de attitude met betrekking tot inkomensnivellering op met als doel hun intermediërende effect te toetsen. Deze modellen vormen het uitgangspunt om te besluiten of onze hypothesen over de individuele en de contextuele variabelen al dan niet bevestigd worden.

Tot slot kijken we in model 3 tot en met 6 naar cross-level interacties. Alle continue variabelen zijn gecentreerd op hun gemiddelde, zodat de interacties een zinvolle interpretatie kennen. Om schattingsproblemen te voorkomen en het aantal vrijheidsgraden niet te zeer te beperken, hebben we ervoor gekozen om niet alle cross-level interacties in één model op te nemen.

\section{Resultaten}

\section{I Beschrijvende statistieken}

In figuur 1 is zowel het percentage personen met een extreem linkse als het percentage personen met een extreem rechtse oriëntatie weergegeven voor dertig Europese landen. De landen zijn van hoog naar laag geor- 


\begin{tabular}{|c|c|c|c|c|}
\hline & Minimum & Maximum & Gemiddelde & S.D. \\
\hline \multicolumn{5}{|l|}{ Individuele variabelen $(N=176.803)$} \\
\hline \multicolumn{5}{|l|}{ Links-rechts zelfplaatsing } \\
\hline Extreem links & 0 & 1 & 0,055 & \\
\hline Links & 0 & 1 & 0,159 & \\
\hline Centrum & 0 & 1 & 0,536 & \\
\hline Rechts & 0 & 1 & 0,191 & \\
\hline Extreem rechts & 0 & 1 & 0,060 & \\
\hline \multicolumn{5}{|l|}{ Opleidingsniveau } \\
\hline Primair & 0 & 1 & 0,297 & \\
\hline Secundair & 0 & 1 & 0,394 & \\
\hline Tertiair & 0 & 1 & 0,303 & \\
\hline \multicolumn{5}{|l|}{ Beroep } \\
\hline Hoofdarbeid & 0 & I & 0,339 & \\
\hline Handarbeid & 0 & 1 & 0,159 & \\
\hline Werkloos & 0 & 1 & 0,057 & \\
\hline Overige & 0 & 1 & 0,458 & \\
\hline Religie (niet-religieus $=1$ ) & 0 & 1 & 0,400 & \\
\hline \multicolumn{5}{|l|}{ Intermediërende variabelen } \\
\hline Ervaren etnische dreiging & 0 & 30 & 14,407 & 6,110 \\
\hline Attitude inkomensnivellering & 1 & 5 & 3,819 & 1,047 \\
\hline \multicolumn{5}{|l|}{ Controlevariabelen } \\
\hline Etniciteit (allochtoon = I) & 0 & I & 0,132 & \\
\hline Leeftijd (//0) & 1,8 & 12,3 & 4,863 & 1,758 \\
\hline \multicolumn{5}{|l|}{ Burgerlijke staat } \\
\hline Gehuwd & 0 & 1 & 0,553 & \\
\hline Gescheiden & 0 & 1 & 0,106 & \\
\hline Weduwnaar/weduwe & 0 & 1 & 0,103 & \\
\hline Ongehuwd & 0 & I & 0,255 & \\
\hline Geslacht (man = I) & 0 & 1 & 0,477 & \\
\hline Aantal kinderen & 0 & 12 & 0,681 & 1,002 \\
\hline \multicolumn{5}{|l|}{ Opleidingsniveau ouders } \\
\hline Primair & 0 & 1 & 0,498 & \\
\hline Secundair & 0 & 1 & 0,279 & \\
\hline Tertiair & 0 & 1 & 0,185 & \\
\hline \multicolumn{5}{|l|}{ Ronde ESS } \\
\hline 1 & 0 & 1 & 0,184 & \\
\hline 2 & 0 & 1 & 0,205 & \\
\hline 3 & 0 & 1 & 0,196 & \\
\hline 4 & 0 & I & 0,239 & \\
\hline 5 & 0 & 1 & 0,175 & \\
\hline \multicolumn{5}{|l|}{ Contextuele variabelen $(N=30)$} \\
\hline Totalitair regime $($ wel $=1)$ & 0 & 1 & 0,533 & \\
\hline Percentage immigranten & 0,6 & 22,9 & 9,287 & 5,498 \\
\hline Percentage werklozen & 3,1 & 13,6 & 7,023 & 2,723 \\
\hline Percentage niet-religeuze personen & 1,7 & 77,3 & 36,264 & 20,166 \\
\hline
\end{tabular}

Bron: European Social Survey, 2002-2010 
dend op grond van het percentage inwoners met een extreem rechtse oriëntatie. Allereerst valt af te lezen dat er geen overduidelijke relatie bestaat tussen het percentage extreem links en het percentage extreem rechts in een land. Naarmate het percentage personen met een extreem rechtse oriëntatie in een land daalt, lijkt het percentage personen met een extreem linkse oriëntatie in een land namelijk niet structureel toe of af te nemen. De correlatie tussen het percentage personen met een extreem linkse en personen met een extreem rechtse oriëntatie is daarentegen redelijk sterk en duidt op een positieve relatie $(\rho=0.575)$. Verder vinden we grote landverschillen. Zo blijkt uit de figuur dat in Cyprus $16,7 \%$ van de bevolking zichzelf als extreem rechts beschouwt. Slechts $1,8 \%$ van de Duitsers vindt zichzelf extreem rechts. Op extreem links gebied zijn Cyprus $(16,1 \%)$ en Bulgarije $(12,9 \%)$ de koplopers. Het laagste percentage personen met een extreem linkse oriëntatie vinden we in Finland $(2,3 \%)$.

Figuur 1 Percentage personen met een extreem linkse en extreem rechtse politieke oriëntatie per land

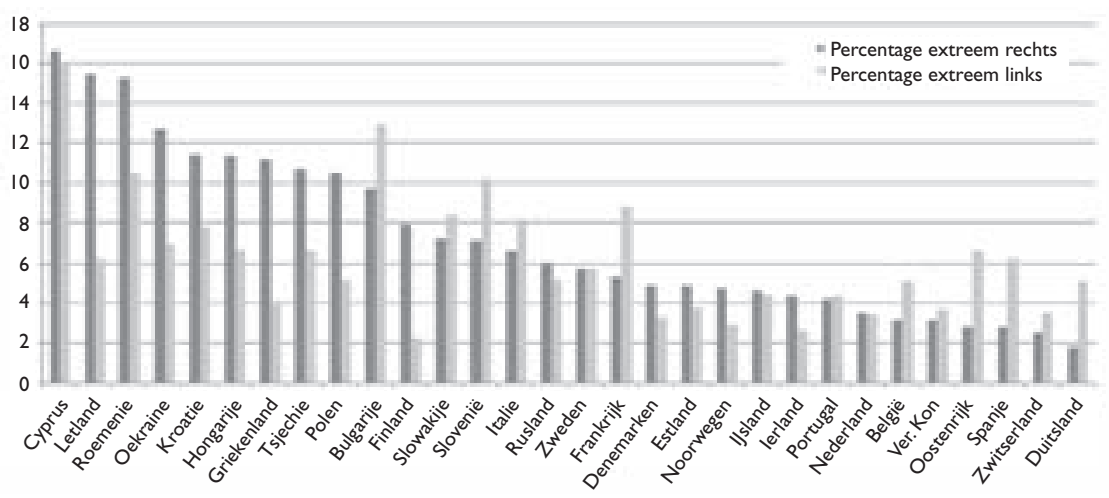

Noot: Landen geordend van hoog naar laag naar percentage extreem rechts.

Bron: European Social Survey, 2002-2010

\subsection{Individuele effecten}

Om te beginnen bespreken we de effecten van de individuele kenmerken op de kans op een extreem rechtse politieke oriëntatie. Uit tabel 2 (model 1) blijkt dat lager opgeleiden ( $b=0,144 ; b=0,053)$, handarbeiders $(b=0,066)$ en werklozen $(b=0,199)$ een grotere kans bezitten om een extreem rechtse oriëntatie te hebben. Vervolgens voegen we in model 2 ervaren etnische dreiging toe. Allereerst blijkt dan dat etnische dreiging inderdaad een positief effect heeft op de kans op een extreem rechtse oriëntatie $(b=0,039)$. Daarnaast blijkt dat deze factor bijna geheel het 
verband tussen enerzijds opleiding en anderzijds de kans op rechts extremisme verklaart. Etnische dreiging verklaart zelfs volledig waarom handarbeiders een grotere kans hebben om extreem rechts te zijn. Lager opgeleiden en handarbeiders hebben kortom een grotere kans op een extreem rechtse oriëntatie, omdat zij meer etnisch dreiging ervaren. Etnische dreiging verklaart echter niet het effect van werkloosheid. Dit betekent dat we onze intermediërende hypothese grotendeels kunnen bevestigen. Verder bezitten niet-religieuze personen een kleinere kans op een extreem rechtse oriëntatie $(b=-0,253)$. Vergeleken met religieuze personen is hun kans om extreem rechts te zijn ten opzichte van de kans om niet extreem rechts te zijn $22 \%\left(e^{-0,253}-1\right)$ lager. Dit effect is niet volgens onze verwachting.

De resultaten voor een extreem linkse oriëntatie staan weergegeven in tabel 3 (model 1 en 2). Ook hier blijkt sociale klasse van invloed. Zo zien we dat inderdaad zowel handarbeiders $(b=0,127)$ als werklozen $(b$ $=0,304)$ een grotere kans hebben om links extremistisch te zijn. Verder merken we op dat primair en secundair opgeleiden een grotere kans hebben om extreem links te zijn vergeleken met tertiair opgeleiden $(b$ $=0,129 ; b=0,034)$. Voegen we vervolgens de attitude van personen met betrekking tot inkomensnivellering toe, dan blijkt dat voor secundair opgeleiden het effect niet meer aanwezig is. Het effect voor primair opgeleiden wordt deels verklaard. Ook voor handarbeiders blijkt de gewenste mate van inkomensnivellering een gedeeltelijke verklaring. Personen die vinden dat de overheid inkomensverschillen moet reduceren, hebben een grotere kans op een extreem linkse oriëntatie $(b=$ 0,422 ). Uit de resultaten blijkt dus dat lager opgeleiden en handarbeiders een grotere kans bezitten om extreem linkse denkbeelden aan te hangen, omdat zij vinden dat de overheid inkomensongelijkheid moet bestrijden. Het effect van werkloosheid wordt echter niet gemedieerd. Wederom kunnen we onze intermediërende hypothese deels bevestigen. Tot slot is religie een determinant van links extremisme. Niet-religieuze personen hebben in vergelijking met religieuze personen - overeenkomstig onze hypothese - een grotere kans om extreem links te zijn ( $b=$ 0,619 ). De kans om wel extreem links te zijn ten opzichte van de kans om niet extreem links te zijn, is bijna tweemaal zo groot voor niet-religieuze personen $\left(\mathrm{e}^{0,619}\right)$.

\subsection{Contextuele effecten}

Vervolgens bespreken we de invloed van de landkenmerken op extreem rechts (tabel 2, model 2) en extreem links (tabel 3, model 2). Allereerst kunnen we onze macrohypothese betreffende totalitaire regimes bevestigen. Personen die leven in een land dat ooit een totalitair regime heeft 
Tabel 2 Logistische multiniveau-analyse extreem rechts, logit-effecten ( $N=139.079)$

\begin{tabular}{|c|c|c|c|c|c|c|}
\hline & MI & M2 & M3 & M4 & M5 & M6 \\
\hline \multicolumn{7}{|l|}{ Individuele variabelen } \\
\hline \multicolumn{7}{|l|}{ Opleiding (tertiair = ref.) } \\
\hline Primair & $0,144 * * *$ & $0,064^{*}$ & 0,081 & 0,053 & 0,053 & $0,060 *$ \\
\hline Secundair & $0,053^{*}$ & 0,006 & 0,052 & 0,007 & 0,006 & 0,005 \\
\hline \multicolumn{7}{|l|}{ Beroep (hoofdarbeid = ref.) } \\
\hline Handarbeid & $0,066^{*}$ & 0,029 & 0,036 & 0,070 & 0,056 & 0,031 \\
\hline Werkloos & $0,199 * * *$ & $0,159 * * *$ & $0,175^{* * * *}$ & $0,187^{* * *}$ & 0,211 **** & $0,161 * * * *$ \\
\hline Overige & $0,270 * * *$ & $0,252 * * * *$ & $0,260 * * *$ & $0,27 I^{* * * *}$ & $0,267 * * *$ & $0,252^{* * * *}$ \\
\hline Niet-religieus (religieus = ref.) & $-0,243 * * *$ & $-0,253^{* * *}$ & 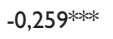 & $-0,257^{* * * *}$ & $-0,257^{* * * *}$ & $-0,282^{* * * *}$ \\
\hline Attitude inkomensnivellering & $-0,178 * * *$ & $-0,188^{* * * *}$ & $-0,186 * * *$ & $-0,187^{* * * k}$ & $-0,187^{* * *}$ & $-0,188 * * *$ \\
\hline \multicolumn{7}{|l|}{ Intermediërende variabele } \\
\hline Ervaren etnische dreiging & & 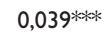 & 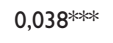 & $0,039 * * * *$ & $0,039 * * * *$ & $0,039 * * * *$ \\
\hline \multicolumn{7}{|l|}{ Contextuele variabelen } \\
\hline Totalitair regime (geen $=$ ref.) & $0,837 * * * *$ & $0,766 * * * *$ & $0,607 * * * *$ & $0,699 * * * *$ & $0,695 * * *$ & $0,731 * * *$ \\
\hline Percentage immigranten & $-0,016$ & $-0,021$ & $-0,039$ & $-0,030$ & $-0,015$ & $-0,022$ \\
\hline Percentage werklozen & 0,011 & 0,008 & 0,013 & 0,008 & 0,011 & 0,009 \\
\hline Percentage niet-religieuzen & $-0,270$ & $-0,339$ & $-0,440$ & $-0,440$ & $-0,429$ & $-0,464$ \\
\hline \multicolumn{7}{|l|}{ Cross-level interacties } \\
\hline Perc. immigranten*primair & & & $0,029 *$ & & & \\
\hline Perc. immigranten*secundair & & & $0,016 *$ & & & \\
\hline Perc. werklozen* primair & & & 0,010 & & & \\
\hline Perc. werklozen* secundair & & & $-0,013$ & & & \\
\hline Perc. immigranten*handarbeid & & & & $0,022 *$ & & \\
\hline Perc. immigranten*werkloos & & & & 0,007 & & \\
\hline Perc. immigranten*overige & & & & 0,010 & & \\
\hline Perc. werklozen*handarbeid & & & & & $-0,002$ & \\
\hline Perc. werklozen*werkloos & & & & & $-0,012$ & \\
\hline Perc. werklozen*overige & & & & & $-0,003$ & \\
\hline Perc. niet-religieuzen*niet-religieus & & & & & & $0,580^{*}$ \\
\hline Intercept & $-3,094 * * *$ & $-2,986$ **** & $-2,97 I^{*} * * *$ & $-3,005$ **** & $-2,998 * * * *$ & $-3,018^{* * *}$ \\
\hline Variantie op landniveau & $0,236 * * *$ & $0,33 I^{* * * *}$ & $0,275 * * *$ & $0,270^{* * * *}$ & $0,275^{* * * *}$ & $0,252^{* * * *}$ \\
\hline
\end{tabular}

$*_{p}<0,05,{ }^{*} p<0,01, *_{* *}^{*}<0,001$. Noot: Modellen zijn gecontroleerd voor etniciteit, Iweeftijd, burgerlijke staat, geslacht, aantal kinderen, opleiding ouders en ESS ronde.

Bron: European Social Survey, 2002-2010

gekend na 1945, hebben zowel een grotere kans om extreem links ( $b=$ $0,523)$ als extreem rechts $(b=0,766)$ te zijn dan personen die niet leven in een land dat ooit een totalitair regime heeft gekend na 1945. De kans om wel extreem te zijn tegenover de kans om niet extreem te zijn in landen die wel ooit een dictatuur waren, ligt voor extreem links $69 \%$ $\left(e^{0,523}-1\right)$ hoger en voor extreem rechts $115 \%\left(e^{0,766}-1\right)$ hoger. Het percentage immigranten noch het percentage werklozen in een land blijkt van invloed op de kans op een extreem rechtse oriëntatie. We kunnen onze hypothesen met betrekking tot deze aspecten dus niet bevestigen. 
Het werkloosheidspercentage blijkt wel van invloed op de kans op links extremisme $(b=0,020)$. Wanneer het percentage werklozen in een land een procent stijgt, dan wordt de kans om wel extreem links te zijn versus de kans om niet extreem links te zijn 1.020 maal zo groot $\left(e^{0,020}\right)$. Personen die leven in sterker geseculariseerde samenlevingen bezitten geen grotere of kleinere kans om het links dan wel rechts extremisme aan te hangen.

Tabel 3 Logistische multiniveau-analyse extreem links, logit-effecten ( $N=132.438)$

\begin{tabular}{|c|c|c|c|c|c|c|}
\hline & MI & M2 & M3 & M4 & M5 & M6 \\
\hline \multicolumn{7}{|l|}{ Individuele variabelen } \\
\hline \multicolumn{7}{|l|}{ Opleiding (tertiair = ref.) } \\
\hline Primair & $0,129 * * * *$ & $0,080 * *$ & $0,112 *$ & $0,084^{* *}$ & $0,084 * *$ & $0,093^{* *}$ \\
\hline Secundair & $0,034^{*}$ & $-0,012$ & 0,011 & $-0,005$ & $-0,005$ & $-0,006$ \\
\hline \multicolumn{7}{|l|}{ Beroep (hoofdarbeid = ref.) } \\
\hline Handarbeid & $0,127^{* * * *}$ & $0,085^{* *}$ & $0,085^{* *}$ & $0,112 *$ & $0,109 *$ & $0,089 * *$ \\
\hline Werkloos & $0,304^{* * * * *}$ & 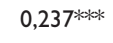 & $0,238 * * * *$ & 0,279 ***⿰冫⿰亅⿱丿丶丶 & 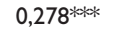 & $0,233^{* * * *}$ \\
\hline Overige & $0,149 * * * *$ & $0,14 \mid * * * *$ & $0,141 * * *$ & $0,143^{* * * *}$ & 0,147 **⿰冫⿰亅⿱丿丶丶 & $0,143^{* * * *}$ \\
\hline Niet-religieus (religieus $=$ ref.) & $0,630 * * * *$ & $0,619 * * * *$ & $0,612 * * *$ & $0,613^{* * * * *}$ & $0,613^{* * * *}$ & $0,565^{* * *}$ \\
\hline Ervaren etnische dreiging & $-0,015^{* * * *}$ & $-0,016 * * *$ & $-0,015^{* * * *}$ & $-0,016 * * * *$ & $-0,016 * * * *$ & $-0,015^{* * * *}$ \\
\hline \multicolumn{7}{|l|}{ Intermediërende variabele } \\
\hline Attitude inkomensnivellering & & $0,422 * * * *$ & $0,423 * * *$ & $0,42 I^{*} * * *$ & 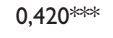 & $0,418 * * *$ \\
\hline \multicolumn{7}{|l|}{ Contextuele variabelen } \\
\hline Totalitair regime (geen = ref.) & $0,591 * *$ & $0,523 * *$ & $0,579 * *$ & $0,507 * *$ & $0,5 \mid 2 * *$ & $0,46 I^{* *}$ \\
\hline Percentage immigranten & $-0,014$ & $-0,013$ & $-0,009$ & $-0,008$ & $-0,012$ & $-0,007$ \\
\hline Percentage werklozen & $0,024^{* *}$ & $0,020 * *$ & 0,016 & $0,021 * *$ & 0,031 **** & $0,022 * *$ \\
\hline Percentage niet-religieuzen & $-0,197$ & $-0,147$ & $-0,088$ & $-0,234$ & $-0,179$ & 0,294 \\
\hline \multicolumn{7}{|l|}{ Cross-level interacties } \\
\hline Perc. immigranten*primair & & & $-0,006$ & & & \\
\hline Perc. immigranten*secundair & & & $-0,001$ & & & \\
\hline Perc. werklozen* primair & & & $-0,006$ & & & \\
\hline Perc. werklozen* secundair & & & 0,012 & & & \\
\hline Perc. immigranten*handarbeid & & & & 0,012 & & \\
\hline Perc. immigranten*werkloos & & & & $0,035^{* *}$ & & \\
\hline Perc. immigranten*overige & & & & $-0,019 *$ & & \\
\hline Perc. werklozen*handarbeid & & & & & $-0,001$ & \\
\hline Perc. werklozen*werkloos & & & & & $-0,017$ & \\
\hline Perc. werklozen*overige & & & & & $-0,017$ & \\
\hline Perc. niet-religieuzen*niet-religieus & & & & & & $-0,992 * *$ \\
\hline Intercept & $-3,311 * * * *$ & $-3,340 * * * *$ & $-3,393 * * *$ & $-3,349 * * * *$ & $-3,348 * * * *$ & $-3,256^{* * * *}$ \\
\hline Variantie op landniveau & $0,222 * * * *$ & $0,220 * * * *$ & $0,212 * * *$ & $0,22 I^{* * * * *}$ & 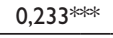 & 0,237 *** \\
\hline
\end{tabular}

$*_{p}<0,05, *_{p} p<0,01, * * * p<0,001$. Noot: Modellen zijn gecontroleerd voor etniciteit, leeftijd, burgerlijke staat, geslacht, aantal kinderen, opleiding ouders en ESS ronde.

Bron: European Social Survey, 2002-2010 


\subsection{Cross-level interactie effecten}

Uit tabel 2 met betrekking tot rechts extremisme (model 3) valt af te lezen dat voor primair en secundair opgeleiden de kans op een extreem rechtse oriëntatie ten opzichte van tertiair opgeleiden relatief groter is, naarmate het percentage immigranten in een land stijgt $(b=0,029$; $b=0.016)$. De hoofdeffecten van primaire en secundaire opleiding zijn namelijk positief $(b=0.081 ; b=0.052)$. We kunnen de bijbehorende hypothese bevestigen. Wanneer we het land met het laagste percentage immigranten (Roemenië: 0,6\%) vergelijken met het land met het hoogste percentage immigranten (Zwitserland: 22,9\%), blijkt dat het effect van opleidingsniveau aanzienlijk verschilt tussen deze landen. In dit geval is het verschil in de regressiecoëfficiënt voor primair opgeleiden $(22,9$ - 0,6) $0,029=0,647$. Het percentage immigranten heeft geen invloed op het individuele effect van werkloosheid, maar wel op dat van handarbeid (model 4): hoe hoger het percentage immigranten in een land, des te sterker het positieve effect van handarbeid op de kans op een extreem rechtse oriëntatie $(b=0,070+0,022)$.

Verder verwachtten we dat het percentage werklozen in een land van invloed is op het opleidings- en beroepseffect op de kans op een extreem rechtse oriëntatie. Dit is niet het geval (model 3 en 5). Wel blijkt uit model 6 dat niet-religieuze personen een grotere kans op een extreem rechtse oriëntatie hebben, wanneer zij leven in landen met een hoger percentage niet-religieuze personen. Gemiddeld over landen is het hoofdeffect van religie negatief $(b=-0.282)$. Echter wanneer het percentage niet-religieuze personen in een samenleving $1 \%$ hoger ligt dan het gemiddelde over landen (ongeveer 36\%), wordt het effect van religie op het individuele niveau positief $(b=-0,282+0,580)$, indicerend dat nietreligieuze personen in dat geval een grotere kans hebben om het rechts extremisme aan te hangen in vergelijking met religieuze personen. We vinden daarmee ondersteuning voor onze laatste cross-level interactie hypothese als het gaat om extreem rechts.

In tabel 3 zijn de cross-level interactie effecten voor een extreem linkse oriëntatie weergegeven. Allereerst valt uit model 4 af te lezen dat hoewel we hier geen verwachting over hadden - het individuele effect van werkloosheid verschilt, naargelang het percentage immigranten in een land stijgt. In landen waar meer immigranten wonen, is de kans voor werklozen om extreem links te zijn in vergelijking met hoofdarbeiders groter $(b=0,035)$. Het hoofdeffect van werkloos is hierbij positief $(b$ $=0,279$ ).

Onze verwachting dat lager opgeleiden, handarbeiders en werklozen een grotere kans hebben op een extreem linkse oriëntatie in landen met een hoger percentage werklozen wordt niet bevestigd (model 3 en 5). Tot slot blijkt uit model 6 dat naarmate het percentage niet-religieuze perso- 
nen in een samenleving toeneemt, de kans voor niet-religieuze personen om links extremistisch te zijn daalt $(b=0.565-0,992)$, waar we dit niet hadden verwacht.

\subsection{Extreem links en extreem rechts vergeleken}

Onze explorerende analyse van het contrast tussen extreem links en extreem rechts toont dat niet-religieuze personen een grotere kans op

Tabel 4 Logistische multiniveau-analyse extreem links versus extreem rechts (ref.), logit-effecten $(\mathrm{N}=20.268)$

\begin{tabular}{|c|c|c|c|c|c|c|}
\hline & MI & M2 & M3 & M4 & M5 & M6 \\
\hline \multicolumn{7}{|l|}{ Individuele variabelen } \\
\hline \multicolumn{7}{|l|}{ Opleiding (tertiair $=$ ref.) } \\
\hline Primair & 0,014 & 0,006 & 0,022 & 0,032 & 0,032 & 0,034 \\
\hline Secundair & $-0,015$ & $-0,039$ & $-0,050$ & $-0,029$ & $-0,030$ & $-0,030$ \\
\hline \multicolumn{7}{|l|}{ Beroep (hoofdarbeid = ref.) } \\
\hline Handarbeid & $0,106^{*}$ & $0,092^{*}$ & $0,092^{*}$ & 0,085 & 0,076 & $0,096^{*}$ \\
\hline Werkloos & $0,130 *$ & 0,073 & 0,075 & 0,120 & 0,128 & 0,064 \\
\hline Overige & $-0,165^{* *}$ & $-0,136 * *$ & $-0,133 * *$ & $-0,156$ & $-0,190$ & $-0,136 * *$ \\
\hline Niet-religieus (religieus $=$ ref.) & $1,\left.03\right|^{* * * *}$ & $1,018 * * *$ & $1,012^{* * *}$ & $1,019 * * *$ & $1,019 * * * *$ & $1,088^{* * * *}$ \\
\hline \multicolumn{7}{|l|}{ Intermediërende variabelen } \\
\hline Ervaren etnische dreiging & & $-0.037 * * *$ & 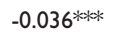 & $-0.037^{* * * *}$ & 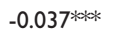 & $-0.036 * * *$ \\
\hline Attitude inkomensnivellering & & $0.557^{* * * *}$ & $0.558 * * *$ & $0.553^{* * * *}$ & $0.553^{* * * *}$ & $0.554^{* * * *}$ \\
\hline \multicolumn{7}{|l|}{ Contextuele variabelen } \\
\hline \multicolumn{7}{|l|}{ Totalitair regime } \\
\hline (geen = ref.) & $-0,172$ & $-0,210$ & $-0,160$ & $-0,182$ & $-0,167$ & $-0,086$ \\
\hline Percentage immigranten & $-0,001$ & 0,001 & 0,028 & 0,020 & 0,002 & 0,006 \\
\hline Percentage werklozen & 0,025 & 0,020 & 0,010 & 0,022 & $0,035^{*}$ & 0,017 \\
\hline Percentage niet-religieuzen & 0,152 & 0,409 & 0,389 & 0,466 & 0,464 & $1,034^{*}$ \\
\hline \multicolumn{7}{|l|}{ Cross-level interacties } \\
\hline Perc. immigranten*primair & & & $-0,033$ & & & \\
\hline Perc. immigranten*secundair & & & $-0,022$ & & & \\
\hline Perc. werklozen* primair & & & $-0,027$ & & & \\
\hline Perc. werklozen* secundair & & & 0,029 & & & \\
\hline Perc. immigranten*handarbeid & & & & $-0,008$ & & \\
\hline Perc. immigranten*werkloos & & & & 0,018 & & \\
\hline Perc. immigranten*overige & & & & $-0,036$ & & \\
\hline Perc. werklozen*handarbeid & & & & & 0,001 & \\
\hline Perc. werklozen*werkloos & & & & & $-0,024$ & \\
\hline Perc. werklozen*overige & & & & & $-0,021$ & \\
\hline Perc. niet-religieuzen*niet-religieus & & & & & & $-1,893 * *$ \\
\hline Intercept & $-0,474 * * * *$ & $-0,38 \mid$ **** & $-0,385 * * * *$ & $-0,383^{* * * *}$ & $-0,392^{* * * ⿰ ㇇ ⿰ 亅 ⿱ 丿 丶 丶 ~}$ & $-0,415^{* * * *}$ \\
\hline Variantie op landniveau & $0,322^{* * * *}$ & 0,330 **** & $0,545^{* * *}$ & $0,610 * * * *$ & 0,530 **⿰冫⿰亅⿱丿丶丶 & 0,330 **** \\
\hline
\end{tabular}

${ }^{*} p<0,05,{ }^{* *} p<0,01, *^{* * *} p<0,001$. Noot: Modellen zijn gecontroleerd voor etniciteit, leeftijd, burgerlijke staat, geslacht, aantal kinderen, opleiding ouders en ESS ronde.

Bron: European Social Survey, 2002-2010 
een extreem linkse oriëntatie in vergelijking tot extreem rechts dan religieuze personen $(b=1.018)$. Ook heeft men een grotere kans op een extreem linkse oriëntatie, wanneer men van mening is dat de overheid inkomensverschillen dient te reduceren $(b=0,557)$. Verder zien we dat personen die meer etnische dreiging ervaren een kleinere kans hebben op een links extremistische oriëntatie $(b=-0,037)$. Allochtonen, gescheiden personen en weduwnaars/weduwes hebben een grotere kans hebben om links extremistisch te zijn. Mannen hebben daarentegen een kleinere kans dan vrouwen op een extreem linkse oriëntatie te zijn vergeleken met extreem rechts. Samenvattend suggereren de verbanden dat op het individuele niveau het hoefijzermodel niet op gaat. Echter, er zijn geen significante landkenmerken die verschillen tussen beide extreme oriëntaties verklaren (tabel 4, model 2). Dit zou een voorlopige bevestiging van de hoefijzerhypothese op landniveau betekenen.

\section{Conclusies en discussie}

In deze bijdrage hebben we onderzocht in hoeverre micro- en macrofactoren extreem linkse en extreem rechtse politieke oriëntaties in Europa verklaren. Daarbij is in internationaal sociaal-wetenschappelijk perspectief vooral onze studie naar extreem links vernieuwend. Verklarende cross-nationale studies naar extreem links zijn namelijk niet tot nauwelijks verricht. Bovendien hebben we bestudeerd welke mechanismen ertoe leiden dat bepaalde sociale klassen zowel vaker extreem links als extreem rechts kunnen zijn. Tevens is met onze studie een aanzet gegeven voor het vergelijken van aanhangers van extreem linkse en extreem rechtse denkbeelden. Door kenmerken van landen en van individuen tegelijkertijd te integreren in een multiniveau-analyse met dertig Europese landen is het inzicht in de determinanten van politiek extremisme vergroot.

Zoals eigenlijk altijd wordt gevonden in de bestaande literatuur (onder andere Kitschelt, 1995; Lubbers e.a., 2002; Norris, 2005; Rydgren, 2008), blijkt dat ervaren etnische dreiging de kans op een extreem rechtse oriëntatie vergroot en dat etnische dreiging (grotendeels) verklaart waarom personen met een lager opleidingsniveau en uit lagere sociale klassen vaker extreem rechts zijn. Dit is in overeenstemming met de etnische competitietheorie. Personen met een lager opleidingsniveau en uit lagere sociale klassen ervaren dreiging van etnische minderheden in de concurrentie om bijvoorbeeld banen en woningen. Zij houden er vaker een extreem rechtse oriëntatie op na, omdat rechts extremistische bewegingen zich ook profileren met anti-immigranten standpunten (Rydgren, 2007).

Lager opgeleiden en personen uit lagere sociale klassen hebben ook 
een grotere kans op een links extremistische oriëntatie, maar hier verklaart de houding met betrekking tot de gewenste mate van inkomensnivellering waarom de kans op een extreem linkse oriëntatie groter is voor deze sociale groepen. Lager opgeleiden en handarbeiders hebben dus vaker een extreem linkse alsook een extreem rechtse oriëntatie, hoewel het mechanisme dat hier achter schuilgaat voor beide extremen verschilt. Toekomstig onderzoek zou zich kunnen richten op het toetsen van alternatieve intermediërende attitudes voor beide extremen, bijvoorbeeld in hoeverre men denkt politieke invloed te hebben of in hoeverre men vertrouwen heeft in de politiek.

Ook is aangetoond dat niet-religieuze personen een kleinere kans hebben op een extreem rechtse oriëntatie. Onze gedachtegang wat betreft symbolische belangen wordt hiermee tegengesproken. Als een mogelijke verklaring kan gedacht worden aan aspecten van religieus extremisme. Binnen Europa zijn bepaalde geloofsovertuigingen erg conservatief en aanhangers van dergelijke religies zullen zichzelf daarom op een links-rechts dimensie vaak uiterst rechts plaatsen. Niet-religieuze personen kunnen daarentegen wel een substituut voor integratie vinden in het andere politieke uiteinde, te weten extreem links. De theorie van symbolische belangen vindt voor links extremisme derhalve wel bevestiging.

Onze studie heeft ook inzichten op het landniveau opgeleverd. In lijn met onze theoretische verwachtingen hebben personen die wonen in een land dat na de Tweede Wereldoorlog een totalitair regime heeft gekend een grotere kans op zowel een extreem linkse als een extreem rechtse politieke oriëntatie. Een dictoriaal verleden lijkt zodoende een voedingsbodem te zijn voor extremisme. Tot op heden is deze relatie nooit zo uitgesproken aangetoond. Ons onderzoek wijst verder uit dat een hoger werkloosheidspercentage in een land, samengaat met een grotere kans om links extremistisch te zijn. Deze bevinding is in lijn met de sociale dominantietheorie, die stelt dat onzekere tijden ervoor kunnen zorgen dat individuen vaker extreme posities innemen.

Samenvattend vinden we vooral ondersteuning voor de sociologische benadering, waarin groepslidmaatschap invloed uitoefent op iemands politieke oriëntatie. Zo bieden onder andere opleiding, sociale klasse en religie een verklaring voor politiek extremisme. Daarnaast concluderen we dat ook de sociaal-psychologische benadering, die zich richt op attitudes en percepties, van belang is bij het verklaren van extreme oriëntaties. Zowel ervaren etnische dreiging als de gewenste mate van inkomensnivellering zijn namelijk intermediërende factoren. Verder vinden we wisselende resultaten wat betreft de sociale dominantietheorie. Zo vinden we bijvoorbeeld ondersteuning voor deze theorie met betrekking tot het effect van het werkloosheidspercentage in een land op de kans op 
links extremisme. Echter, wanneer we personen met een extreem linkse en extreem rechtse oriëntatie met elkaar vergelijken, dan vinden we nauwelijks overeenkomsten tussen beide, wat er op duidt dat de sociale dominantietheorie niet opgaat.

Tot slot is het in cross-nationaal onderzoek gebruikelijk om stemgedrag te gebruiken om zo inhoudelijke kenmerken te kunnen introduceren van politieke partijen. Door zelfplaatsing te kiezen als te verklaren kenmerk, wordt voorbijgegaan aan deze aanbodzijde in het politieke landschap. Nader onderzoek is nodig om te bepalen in hoeverre het aanbod van partijen in het bijzonder links extremisme kan verklaren. Ook is het interessant om een dynamische benadering te hanteren in het analyseren van extreme oriëntaties. Voor zowel personen met een extreem linkse als personen met een extreem rechtse oriëntatie is te bepalen hoe zij zichzelf beschouwen door de tijd en welke factoren hierop van invloed zijn. Een dergelijke methode wordt zelden gehanteerd in hedendaags onderzoek naar rechts extremisme. Op het gebied van personen met een links extremistische oriëntatie valt op dit terrein nog meer winst te boeken.

\section{Noten}

1. Mark Visser en Gerbert Kraaykamp zijn verbonden aan de sectie Sociologie van de Radboud Universiteit Nijmegen: Mark Visser als student van de Research Master Social Cultural Science, Gerbert Kraaykamp als hoogleraar Empirische Sociologie. Eva Jaspers is werkzaam als universitair docent op de Afdeling Sociologie van de Universiteit Utrecht. Correspondentie naar: M. Visser, Radboud Universiteit Nijmegen, Sectie Sociologie/ICS, Postbus 9104, 6500 HE Nijmegen, email: m.visser@student.ru.nl.

2. Het voornaamste onderscheid in de literatuur is dat tussen de definities extreem en radicaal. Radicaal staat hierbij voor de oppositie tegenover de fundamentele waarden van de democratie, terwijl extreem staat voor het verwerpen van het gehele democratische systeem. De term extreem lijkt zodoende niet erg aan te sluiten op de ideologie van politieke partijen. Echter, de term extreem is wel degelijk van toepassing op de politieke oriëntatie van personen.

3. De dertig landen zijn: België, Bulgarije, Cyprus, Denemarken, Duitsland, Estland, Finland, Frankrijk, Griekenland, Hongarije, Ierland, IJsland, Italië, Kroatië, Letland, Nederland, Noorwegen, Oekraïne, Oostenrijk, Polen, Portugal, Roemenië, Rusland, Slovenië, Slowakije, Spanje, Tsjechië, Verenigd Koninkrijk, Zweden en Zwitserland. Israël is vanwege missende waarden op cruciale variabelen in ons onderzoek buiten beschouwing gelaten. Luxemburg is niet meegenomen omwille de afwijkende en ontbrekende gegevens op landniveau. Tot slot is Turkije verwijderd, omdat in dit land extreem rechtse oriëntaties niet vergelijkbaar zijn met de rest van Europa. Het betreft in Turkije eerder een zeer sterke vorm van nationalisme.

4. Contextuele gegevens met betrekking tot het percentage niet-westerse immigranten zijn niet beschikbaar voor alle landen en ESS-ronden. Eerder onderzoek naar extreem rechts heeft ook andere maten getoetst, zoals het percentage asiel- 
zoekers, het percentage niet-staatsburgers en het percentage vluchtelingen (bijvoorbeeld Norris, 2005; Van der Brug e.a., 2005). Deze maten zijn cross-nationaal slecht vergelijkbaar (Schneider, 2008). Wij hanteren daarom het percentage immigranten in een land. Deze informatie is wel beschikbaar voor ieder land in onze data, maar helaas niet voor alle ronden.

\section{Literatuur}

Abramowitz, A.I. \& Saunders, K.L. (2008). Is polarization a myth? Journal of Politics, 70, 542-555.

Adorno, T.W., Frenkel-Brunswik, E., Levinson, D.J., \& Nevitt Sanford, R. (1950). The authoritarian personality. Londen: Harper.

Arendt, H. (1951). The origins of totalitarianism. New York: Hartcourt, Brace \& World.

Arzheimer, K. \& Carter, E. (2006). Political opportunity structures and right-wing extremist party success. European Journal of Political Research, 45, 419-443.

Betz, H. (1994). Radicalism and right-wing populism in Western Europe. New York: St. Martin's Press.

Blalock, H.M. (1967). Toward a theory of minority-group relations. New York: John Wiley \& Sons.

Brug, W. van der (2003). How the LPF fueled discontent. Empirical tests of explanations of LPF support. Acta Politica, 38, 89-106.

Brug, W. van der, Fennema, M., \& Tillie, J. (2005). Why some anti-immigrant parties fail and others succeed. Comparative Political Studies, 38, 537-573.

Carter, E. (2005). The extreme right in Western Europe. Success or failure? Manchester: Manchester University Press.

Clark, T.N., Lipset, S.M., \& Rempel, M. (1993). The declining political significance of social class. International Sociology, 8, 293-316.

Coenders, M. (2001). Nationalistic attitudes and ethnic exclusionism in a comparative perspective. Nijmegen: Radboud Universiteit.

Coenders, M., Lubbers, M., \& Scheepers, P. (2004). Majorities' attitudes towards minorities in Western and Eastern European societies: results from the European Social Survey 2002-2003. Wenen: European Monitoring Centre on Racism and Xenophobia.

Coser, L.A. (1956). The functions of social conflict. Glencoe: Free Press.

Downs, A. (1957). An economic theory of democracy. New York: Harper \& Row. Faye, J. (2004). Langages totalitaires. Parijs: Hermann.

Giddens, A. (1994). Beyond left and right: the future of radical politics. Cambridge: Polity Press.

Gijsberts, M., Hagendoorn, L., \& Scheepers, P. (2004). Nationalism and exclusionism of migrants. Crossnational comparisons. Aldershot: Ashgate. 
Givens, T.E. (2004). The radical right gender gap. Comparative Political Studies, 37, 30-54.

Greenberg, J. \& Jonas, E. (2008). Psychological motives and political orientation. The left, the right, and the rigid: Comment on Jost et al. (2003). Psychological Bulletin, 129, 376-382.

Husbands, C. (1998). De Centrumstroming in perspectief: hoe verschillend is Nederland? In J. van Holsteyn \& C. Mudde (red.), Extreem-rechts in Nederland (pp. 175-192). Den Haag: Sdu Uitgevers.

Inglehart, R.F. (1997). Modernization and postmodernization: cultural, economic and political change in 43 societies. New Jersey: Princeton University Press.

Jost, J.T., Federico, C.M., \& Napier, J.L. (2009). Political ideology: its structure, functions, and elective affinities. Annual Review of Psychology, 60, 307-333.

Kitschelt, H.P. (1995). The radical right in Western Europe. A comparative analysis. Ann Arbor: University of Michigan Press.

Kitschelt, H.P. (2007). Growth and persistence of the radical right in postindustrial democracies: advances and challenges in comparative research. West European Politics, 30, 1176-1206.

Kornhauser, W. (1960). The politics of mass society. Londen: The Free Press.

Lazarsfeld, P.F., Berelson, B.R., \& Gaudet, H. (1944). The people's choice: how the voter makes up his mind in a presidential campaign. New York: Duell, Sloan \& Pearce.

LeVine, R.A. \& Campbell, D.T. (1972). Ethnocentrism: theories of conflict, ethnic attitudes, and group behavior. New York: John Wiley \& Sons.

Lipset, S.M. \& Rokkan, S. (1967). Party systems and voter alignments: crossnational perspectives. Londen: Collier-MacMillan.

Lubbers, M., Gijsberts, M., \& Scheepers, P. (2002). Extreme right-wing voting in Western Europe. European Journal of Political Research, 41, 345-378.

March, L. \& Mudde, C. (2005). What's left of the radical left? The European radical left after 1989: decline and mutation. Comparative European Politics, 3, 23-49.

Mair, P.M.A., Müller, W.C., \& Plasser, F. (2004). Political parties and electoral change: party responses to electoral markets. Londen: Sage.

Middendorp, C. (1991). Ideology in Dutch politics. The democratic system reconsidered 1970-1985. Assen: Van Gorkum.

Mudde, C. (1996). The war of words: defining the extreme right party family. West European Politics, 19, 225-248.

Mudde, C. (2007). Populist radical right parties in Europe. Cambridge: Cambridge University Press.

Need, A. (1997). The kindred vote: individual and family effects of social class and religion on electoral change in the Netherlands 1956-1994. Nijmegen: ICSdissertations. 
Nieuwbeerta, P. (1995). The democratic class struggle in twenty countries 19451990. Amsterdam: Thesis Publishers.

Norris, P. (2005). Radical right. Voters and parties in the electoral market. Cambridge: Cambridge University Press.

Nozick, R. (ed.) (1997). The characteristic features of extremism. In: Socratic puzzles (pp. 296-299). Cambridge: Harvard University Press.

Olzak, S. (1992). The dynamics of ethnic competition and conflict. Stanford: Stanford University Press.

Ooijevaar, J. \& Kraaykamp, G. (2005). Links in beeld. Een explorerend onderzoek naar de sociale kenmerken van extreem links in Nederland. Mens \& Maatschappij, 80, 239-256.

Oosterwaal, A. (2009). Polarisatie in de Nederlandse samenleving en politiek: het integratiebeleid. Mens \& Maatschappij, 84, 369-392.

Pratto, F., Sidanius, J., Stallworth, L.M., \& Malle, B.F. (1994). Social dominance orientation: A personality variable predicting social and political attitudes. Journal of Personality and Social Psychology, 67, 741-763.

Pugh, J. (ed.) (2009). What is radical politics today? New York: Palgrave Macmillan.

Quillian, L. (2006). New approaches to understanding racial prejudice and discrimination. Annual Review of Sociology, 32, 299-328.

Rokeach, M. (1967). The open and closed mind. New York: Basis Books.

Rydgren, J. (2007). The sociology of the radical right. Annual Review of Sociology, 33, 241-262.

Rydgren, J. (2008). Immigration sceptics, xenophobes or racists? Radical right-wing voting in six West European countries. European Journal of Political Research, 47, 737-765.

Scheepers, P. (1996). Etnocentrisme en rechts-extremisme: reacties op de komst en aanwezigheid van etnische minderheden. In: H.B.G. Ganzeboom \& W.C. Ultee (red.), De sociale segmentatie van Nederland in 2015 (pp. 247-301). Den Haag: Sdu Uitgevers.

Scheepers, P., Billiet, J., \& De Witte, H. (1995). Het electoraat van het Vlaams Blok. De verschillende kiezerskorpsen en hun opvattingen. Sociologische Gids, 3, 232-252.

Schneider, S.L. (2008). Anti-immigrant attitudes in Europe: outgroup size and perceived ethnic threat. European Sociological Review, 24, 53-67.

Schumpeter, J.A. (1943). Capitalism, socialism and democracy. Londen: Allen \& Unwin.

Sidanius, J. (1985). Cognitive functioning and sociopolitical ideology revisited. Political Psychology, 6, 637-662.

Sidanius, J. (1993). The psychology of group conflict and the dynamics of oppression: a social dominance perspective. In: W. McGuire \& S. Iyengar (eds.), Current approaches to political psychology (pp. 183-219). Durham: Duke University Press. 
Sidanius, J. \& Pratto, F. (1999). Social dominance: an intergroup theory of social hierarchy and oppression. Cambridge: Cambridge University Press.

Snijders, T.A.B. \& Bosker, R.J. (1999). Multilevel analysis: an introduction to basic and advanced multilevel modeling. Londen: Sage Publishers.

Stenner, K. (2005). The authoritarian dynamic. Cambridge: Cambridge University Press.

Thomassen, J.J.A. (2005). The European voter: a comparative study of modern democracies. Oxford: Oxford University Press.

Verenigde Naties (2006). World population policies 2005. New York: Verenigde Naties. 